\title{
The Occurrence of Cultivated Plants in the Region of Styria from the Palaeolithic till the Middle Ages
}

\author{
Andrej PAUŠIČ゙ $\check{C}^{\star}$ Andrej ŠUŠEK \\ University of Maribor, Faculty of Agriculture and Life Sciences, Pivola 10, 2311 Hoče, Slovenia
}

\begin{abstract}
The aim of this review study was to analyse large paleo-botanical datasets derived from investigations of 35 archaeological sites and published during a longer time period. The presence of 18 selected crop taxa has been monitored in the region of Styria. Our results indicate that in the Copper Age, the cultivation and usage of proso millet (Panicum miliaceum) and the einkorn wheat (Triticum monococcum) was present. From the Bronze Age period, the most commonly grown taxa are barley (Hordeum vulgare), proso millet, emmer wheat (Triticum dicoccum) and spelt wheat (Triticum spelta). In the Iron Age, some new crops emerged along with the already common foxtail millet (Setaria italica) and common flax (Linum usitatissimum), a species first found in Styria during this exact period. The importance of Roman period for Styria lies in the introduction of new taxa like the Persian walnut (Juglans regia), of which remnants were also found in the studied area. The late Antiquity and Middle Ages are a wide time frame where all important cereal taxa were already known from previous periods and were also grown in the studied area, with the exception of oat (Avena sativa) and durum wheat (Triticum durum), of which remnants were absent from this period.
\end{abstract}

Key words: archaeobotany, biogeography, crop domestication, paleobotany, Styria

\section{INTRODUCTION}

One of the most dramatic processes in human history was the transition or human evolution from hunting and gathering to the stage of sedentism (cultivating plants). Between 13,000 and 10,500 years BP (before present), a group of humans in the area of the Near East began to change their lifestyle towards sedentism. At first, communities were most probably composed of hunter-gatherers practicing anticipatory mobility, whose aggregations gradually became permanent settlements, changing their way of life (BelferCohen and Bar-Yosef, 2002).

With the beginning of agriculture, around 10,500 years ago, dramatic changes took place in this longstanding way of life, as human societies independently domesticated a variety of different plants and animals (Jacomet, 2009) in more than a half dozen regions of the world. Food production arose independently in nine different areas of the world; in the Fertile Crescent, China, Mesoamerica, Andes/Amazonia, eastern United States, Sahel, tropical West Africa, Ethiopia and New Guinea (Diamond, 2002). Plant (and animal) domestication marks the beginning of the archaeological period known as the "Neolithic".

The domestication centre, also known as the 'Fertile Crescent' is a region in southwest Asia, comprising the valleys of the Tigris, Euphrates and Jordan rivers and their adjacent hilly flanks. Eight species are considered to be domesticated founder crops in the Levant (i.e., the western "arc" of the Fertile Crescent). These are three cereals: the diploid einkorn wheat (Triticum monococcum L.), tetraploid emmer wheat (Triticum dicoccum Schrank ex Schübl.) and barley (Hordeum vulgare L.), four pulses; lentil (Lens culinaris Medikus), pea (Pisum sativum L.), chickpea (Cicer arietinum L.), bitter vetch (Vicia ervilia (L.) Willd.) and single oil and fibre crop of flax 
(Linum usitatissimum L.) (Weiss and Zohary, 2011).

The use of domesticated plants and animals rapidly spread widely from the Near East across Europe. It appears to have spread first to Greece and the Balkans and subsequently over the rest of Europe. Archaeological evidence produced by radiocarbon dating indicates, that the expanding velocity of farming is roughly constant all over Europe (Ammerman and Cavalli-Sforza, 1971; Ammerman and Cavalli-Sforza, 1984; Gkiasta et al., 2003; Kabir et al., 2018). With the Neolithic agriculturalist spreading across Europe, in the early Holocene, from the southeast (c. 6000 B.C.) to the northwest (c. 3000 B.C.) (Higgs and Jarman, 1972; Jarman et al., 1982), the hunting-gathering way of life, which had prevailed there from the earliest times, was terminated.

In this study, we holistically describe the occourence/ presence of important crop taxa in the Central European area, on the example of the Styria region in Slovenia and Austria. The focus area of interest within this study covers mainly the hilly region of the now eastern and southwestern
Austrian Styria and Slovenian Styria (Štajerska). The aim was to investigate large dataset of paleobotanical data that include all up to date known paleobotanical records from the studied area, from prehistory till the Middle Ages. Our main goal was to present the taxa and their occourence from each studied epoch per-se. Nowadays, the food production in the studied area is used not only to supply the population, but is an essential part of tourism. The results of our study could be used for the revitalization and utilization of indigenous crop species and their inclusion in tourism. The reintroduction of old crops leads to a greater biodiversity and allows local producers to offer new and for tourists attractive products, building their story on the local archaeological heritage.

\section{MATERIAL AND METHODS}

The focus area of interest within this study covers mainly the region of Styria within its historical borders from before 1919,

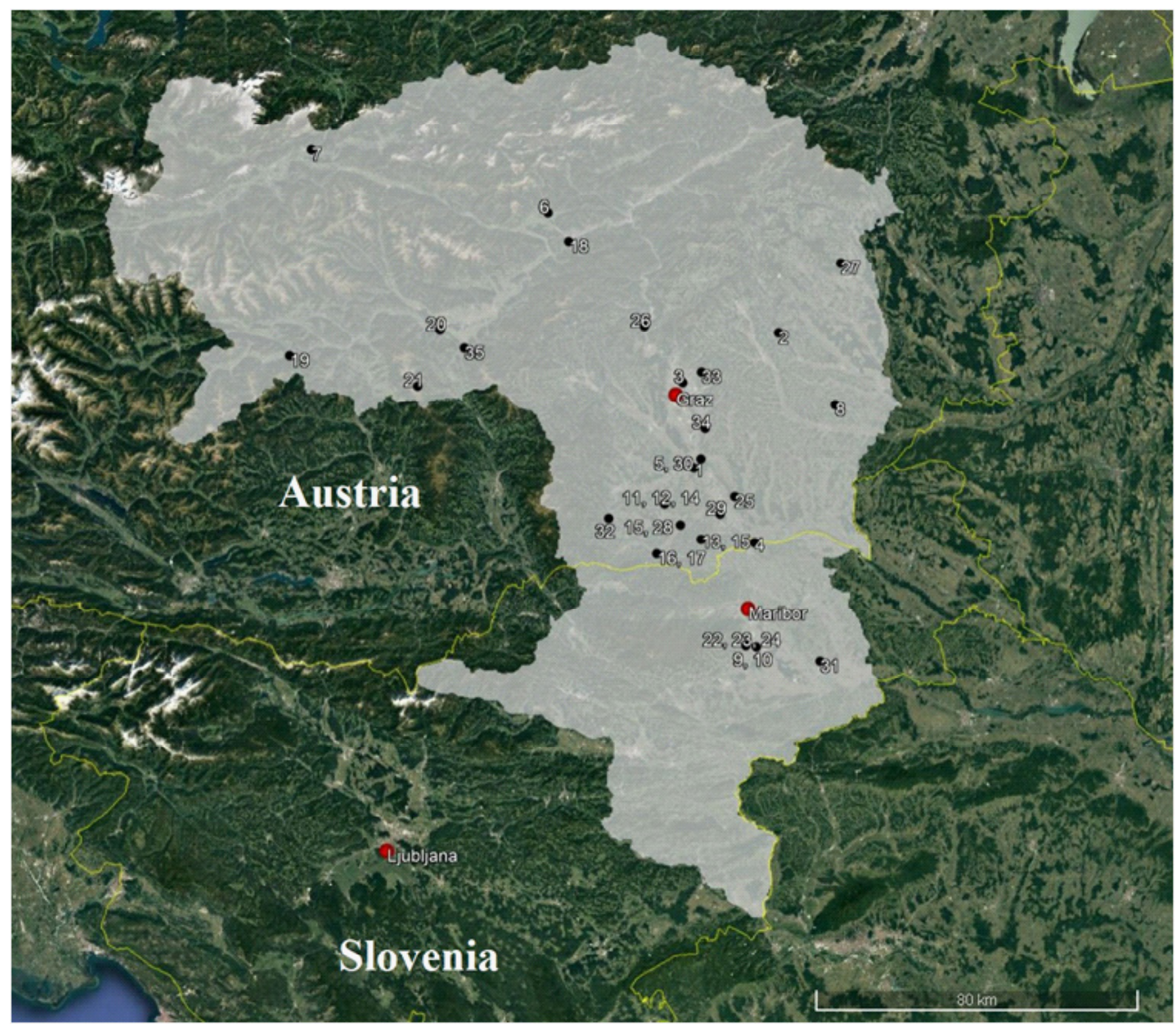

Figure 1. The map represents the studied area, the borders of Styria-Štajerska; the black dots represent the archaeological excavation sites included in this study 
including parts of now eastern and south-western Austrian Styria and Slovenian Styria (Štajerska) (Fig. 1). Both parts of the studied area share similar ecological aspects, such as in geology, soil composition and climatic conditions. This led to similar historical developments in the food supply and thus in the social and cultural development of the region, which is also manifested in its rich archaeological heritage. According to orographic factors, Styria is in general divided into a larger north-western mountainous and alpine region and a smaller south-eastern hilly foreland. In Slovenia, the non-alpine region in the far northeast of the country, already bordering the region, coincides with the Panonian part of Europe, reflecting the increasing (sub) Pannonia biogeographical influences in the eastern part (Herbert, 2018). Our study does not cover excavations in alpine or mountainous areas of Styria, but is limited to the non-alpine part of the area, which is characterized by low absolute altitudes (rarely above 600 m.a.s.l.) and relative altitudes (rarely above $300 \mathrm{~m}$ ).

Within this study, we investigated the dataset of paleobotanical data from 35 archaeological study sites, some of which coincide with the same geographical locality. The remnants found at some archaeological sites chronologically coincide with more historical periods. Investigations at such sites were finalized in more archaeological sectors that coincided with different periods. The archaeological study sites were not organised in both parts (Slovenia, Austria) in the same number, but 28 are from Austria and 7 study sites are from Slovenia (Fig.1). Therefore, the prevailing number of material was found in Austria.

The data about the determined plant taxa found in study sites were obtained from the Inter-Arch Steiermark site (2021).

All the archaeological study sites, included in our study coincide or are located on the ravines, flatland areas or hillyish regions that could be considered ecologically quite a homogenous space. We do not deal with the samples from the pre-Alpine or Alpine areas, nor from say the karstic fields or the Dinaric mountains. As the ecological conditions are quite the same in both parts of our studied area (Slovenia/ Austria), we did not separate those locations additionally in different clusters, regarding the orography or biogeographic characteristic of the terrain as the differences within each site are minor and had not had any influence on the occurrence of different farming practices in the studied epochs (like that of the hilly Alpine space, Pannonian basin or in Mediterranean areas).

Paleobotanical data were derived from six historical epochs: Chalcolithic or Copper Age, Bronze Age, Iron Age (the Hallstatt and the La-Tène periods), Roman period, Late Antiquity and the Middle Ages. The list of investigated archaeological study sites in the studied area with the attributed time frame period is presented in the Table 1.

Table 1: List of investigated archaeological study sites, attributed with the time frame period

\begin{tabular}{|l|l|}
\hline Time epoch & Archaeological excavation sites \\
\hline Copper Age (4,400-2,300 BC) & $\mathbf{( 1 ) * L e i b n i t z ~ 6 6 4 2 5 . 2 ; ~ ( 2 ) W e i z ~ 6 8 2 3 9 . 1 ; ~ ( 3 ) G r a z ~ 6 3 0 1 9 . 4 ; ~ ( 4 ) P e s n i c a ~ 5 6 3 . 1 ~}$ \\
\hline Bronze Age (2,300-900 BC) & $\begin{array}{l}\text { (5)Leibnitz 66413.3; (6)Leoben 60312.1; (7)Liezen 67010.1; (8)Südoststeiermark 62151.2; } \\
\text { (9)Maribor 694.1; (10)Maribor 706.1; (4)Pesnica 563.1 }\end{array}$ \\
\hline $\begin{array}{l}\text { Iron Age (Hallstatt) } \\
\text { (900-420 BC) }\end{array}$ & $\begin{array}{l}\text { (15)Leibnitz 66003.11; (12)Leibnitz 66010.13; (13)Leibnitz 66011.2; (14)Leibnitz 66003.1; } \\
\text { Murau 65318.1; (20)Murtal 65035.1; (21)Südoststeiermark 62113.1; (22)Maribor 679.1; (9) }\end{array}$ \\
\hline $\begin{array}{l}\text { Iron Age (La Tène) } \\
\text { (600-01 BC) }\end{array}$ & $\begin{array}{l}\text { Maribor 694.1; (23)Maribor 704.1; (24)Maribor 707.1; (4)Pesnica 563.1 } \\
\text { Maribor 706.1; (4)Pesnica 563.1 }\end{array}$ \\
\hline $\begin{array}{l}\text { Roman period } \\
\text { (01 BC-5 AD) }\end{array}$ & $\begin{array}{l}\text { (26)Graz 63010.2; (27)Hartberg - Für. 64135.1; (28)Leibnitz 66011.6; (25)Leibnitz 66172.4; } \\
\text { (29)Leibnitz 66188.1; (30)Leibnitz 66425.8; (10)Maribor 706.1; (31)Ptuj 400.10 }\end{array}$ \\
\hline $\begin{array}{l}\text { Late Antiquity (5-7 AD) and } \\
\text { Middle Ages (7-11 AD) }\end{array}$ & $\begin{array}{l}\text { (32)Deutschlandsberg 61057.1; (33)Graz(city) 63101.11; (34)Graz 63254.10; (28)Leibnitz, } \\
\text { 66011.6; (25)Leibnitz 66172.4; (35)Murtal 61011.1 }\end{array}$ \\
\hline
\end{tabular}

*The number in brackets represents the archaeological study site number, as shown on the map (Fig. 1). Each archaeological site is attributed with the archaeological site number. The plant material from some archaeological sites coincides with different time periods, depending on the researched soil layers.

We excluded from this study the potentially edible/usable plants taxa, that were found at the archaeological sites, since we do not have any information about their usage in the past (like parsnip, (Pastinaca sativa L.), wild carrot (Daucus carota L.) and species from the genera Atriplex, Brassica, Polygonum, Sinapis etc.). By now we know those plants are either edible, useful as herbs or even as medical plants. However, we lack any evidence about the usage in the observed time scale. There is some evidence of usage of mentioned herbs in the Roman cuisine, but those were still rather taxa collected by locals in nature and not grown in their gardens. Even for that we completely lack any evidence, for say the Bronze Age. We additionally excluded edible taxa that were found only in one location- once in only one-time epoch (e.g. pomegranate, Punica granatum L.) as we do not have enough information about the trade and usage of taxa through the broader area of study.

\section{RESULTS}

A total of 500 plant remnants were found at 35 study sites in the studied area, belonging to different time epochs. To simplify our additional analysis of data, we appended all the 
data with a time frame attribute (Fig. 2). Most of the remnants were identified from the archaeological sites, belonging to the Iron Age (from Hallstatt period 109 remnants and from La Tène period 75 remnants), Late Antiquity and the Middle Ages (116 plant remnants), and from the Bronze age (108 plant remnants). From the Copper Age and Roman period only 20 and 72 remnants were found respectively. Therefore, the Copper Age represents a time frame, the least remnants were found.

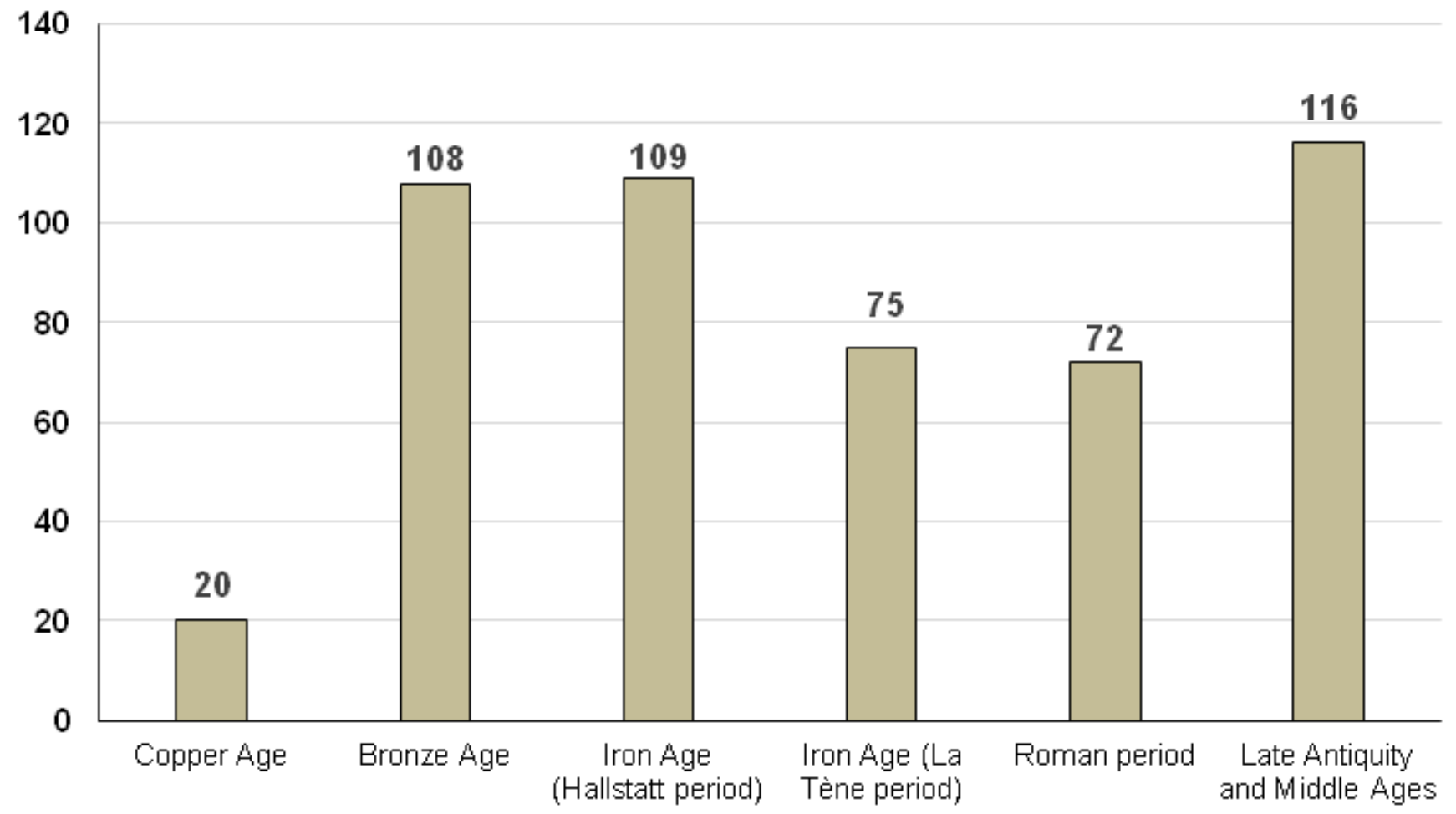

Figure 2: Number of determined plant taxa per time epoch in the studied area of Styria

Through all the investigated time epochs, 18 plant taxa were found that were possibly a staple diet and therefore cultivated by farmers during the observed time frame (Table 2). Some taxa were of course absent in the early time epochs and present in later epochs (and vice-versa). The taxa were divided into four 'artificial' categories, which do not follow the morphological characteristics or phylogenetics of taxa and are rather a simplified representation of the results: 1) cereals and other taxa from the Poaceae family, 2) pulses, 3) trees and shrubs and 4) other cultivated species, morphologically and genetically unrelated annual plant taxa.

For the purpose of studying the occurrence of each plant species, we appended the time frame (in which the species were found at the archaeological sites of the studied area) to each studied plant species (Table 2). It helped us to get a good insight into the occurrence of particular taxon throughout the studied time frame. Additionally, we added the information about the number of studied sites and the species found in a particular time epoch.

\section{DISCUSSION}

Our study indicates a particular trend of occurrence of species remnants in the observed time frame.

In the Neolithic (Stone Age), which began in Styria at about 6,000 BC, first attempts of farming in this part of Europe became evident. For the first time man changed the landscape structure at a bigger scale (the Neolithic revolution), although not as dramatically as in the following time periods (Jacomet, 2009). Currently, we do not own large datasets of determined archaeobotanical material from this time epoch in Styria (Lenneis, 2001).

The Chalcolithic or Copper Age (4,400-2,300 BC). Although there are not many archeobotanical remnants left from that period in the region of Styria (Culiberg, 1999), our study clearly shows the presence of two important crop taxa from that time frame. During the excavations, the remnants of proso millet (Panicum miliaceum L.) and einkorn wheat ( $T$. monococcum) were found in the studied area. The remnants of both taxa were found at two different archaeological excavation sites (Table 2).

However, in the central part of Slovenia (Ljubljana Moor) the remains of domestic plants such as barley (H. vulgare), einkorn wheat ( $T$. monococcum), emmer ( $T$. dicoccum), garden or opium poppy (Papaver somniferum L.), common oat (Avena sativa L.) and even remnants from wild grapevine seed (Vitis vinifera ssp. Sylvestris L.) indicate their early cultivation in that area (Jeraj et al., 2008). Also in Central and South Croatia, a dominance in einkorn and emmer wheat can be observed, followed by barley. Less frequent were findings of proso millet (P. miliaceum) and spelt (Triticum spelta L.), but due to their limited numbers, it is less clear whether they were grown as crops or represented weeds. Pulses (e.g. lentil, pea and grass pea), fruit remains, wild plants and weed species were also found, although more commonly from the late Copper Age sites (Reed, 2016). 
Table 2: The most important crop taxa in Styria through observed time periods, corresponding with the number of study sites the taxa were found

\begin{tabular}{|c|c|c|c|c|c|c|c|}
\hline Taxon/Sc. Name & English name & 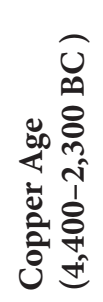 & 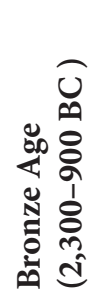 & 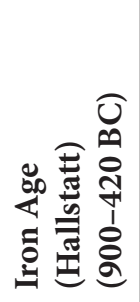 & 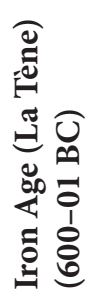 & 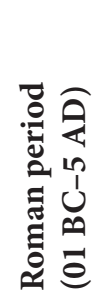 & 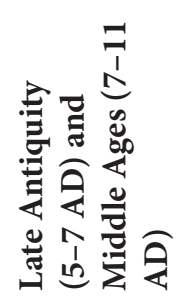 \\
\hline \multicolumn{8}{|l|}{ Cereals } \\
\hline Avena sativa $\mathrm{L}$. & Oat & & & 2 & & & \\
\hline Hordeum vulgare $\mathrm{L}$. & Barley & & 6 & 9 & 5 & 6 & 3 \\
\hline Panicum miliaceum L. & Proso millet & 2 & 6 & 9 & 3 & 5 & 4 \\
\hline Secale cereale $\mathrm{L}$. & Rye & & 1 & 1 & 1 & & 6 \\
\hline Setaria italica (L.) P. Beauvois & Foxtail millet & & 4 & 6 & 3 & 3 & 3 \\
\hline Triticum aestivum $\mathrm{L}$. & Wheat & & 2 & 1 & 2 & 4 & 1 \\
\hline Triticum dicoccon (Schrank) Schuebl. & Emmer & & 5 & 9 & 1 & 2 & 2 \\
\hline Triticum durum Desf. & Durum wheat & & 1 & & 3 & 1 & \\
\hline Triticum monococcum L. & Einkorn wheat & 2 & 2 & 1 & 3 & & 2 \\
\hline Triticum spelta L. & Spelt wheat & & 4 & 5 & 2 & 3 & 2 \\
\hline \multicolumn{8}{|l|}{ Trees and shrubs } \\
\hline Juglans regia $\mathrm{L}$. & Persian walnut & & & & & 2 & 3 \\
\hline Prunus persica (L.) Siebold \& Zucc. & Peach & & & & & & 3 \\
\hline Vitis vinifera $\mathrm{L}$. & Grape vine & & 6 & 2 & 3 & 3 & 2 \\
\hline \multicolumn{8}{|l|}{ Pulses } \\
\hline Lens culinaris Medik. & Lentil & & 9 & 7 & 1 & 1 & 7 \\
\hline Pisum sativum $\mathrm{L}$. & Pea & & 1 & 1 & & 1 & 3 \\
\hline Vicia faba L. & Broad bean & & 2 & 2 & 1 & 1 & 3 \\
\hline \multicolumn{8}{|l|}{ Other } \\
\hline Linum usitatissimum L. & Common flax & & & 2 & 2 & & 1 \\
\hline Papaver somniferum $\mathrm{L}$. & Opium poppy & & 3 & 2 & 1 & & \\
\hline
\end{tabular}

The Bronze Age (2,300-900 BC) is a period from which large quantities of archaeobotanical material were already found. From that period 108 plant remnants were found in Styria, belonging to 14 different taxa (Table 2). According to the number of study sites where plant remains were found, we can conclude that lentil (L. culinaris) (found at 9 study sites), barley (H. vulgare) and proso millet (P. miliaceum) (both taxa were found at 6 study sites), emmer (T. dicoccum) (found at 5 study sites), foxtail millet (Setaria italica (L.) P. Beauvois) and spelt wheat (T. spelta) (fund at 4 study sites) were the most important cultivated plants in human nutrition during this period.

Other cereals that were identified were emmer ( $T$. monococcum), common wheat (Triticum aestivum L.), durum wheat (Triticum durum Desf.) and rye (Secale cereale L.). From the group of trees and shrubs, remnants of the wild grapevine-seed ( $V$. vinifera ssp. sylvestris) were identified at 6 study sites. From pulses, plant remains of broad bean (Vicia faba L.), peas (P. sativum) and also seeds of the garden poppy
(P. somniferum) were found.

Other studies conclude that in the broader Central European area, spelt wheat (T. spelta), emmer ( $T$. monococcum), durum wheat ( $T$. durum), common wheat ( $T$. aestivum), as well as foxtail millet (S. italica), proso millet ( $P$. miliaceum) and some legumes (Vicia spp.) were already known to local farmers, sown and used as an everyday food source (Stika and Heiss, 2013; Reed, 2016)

Our study suggests that this period is one of the most important epochs in Styria, since one can find an astonishing array of cultivated plant taxa in the studied area. It is therefore evident that with the Bronze age, the 'farmers' in the studied area already produced and consumed crop taxa that were important up until the Middle Ages.

The Iron Age (900 BC-01 BC). If we merge the Hallstatt and La Tène periods, our result show that in Styria, the most important crops were barley (H. vulgare) (found at 14 sites), proso millet ( $P$. miliaceum) (found at 12 sites), emmer wheat $(T$. dicoccum) (found at 10 sites), foxtail millet (S. italica) (found at 
9 sites), lentil (L. culinaris) (found at 8 sites) and spelt wheat (T. spelta) (found at 7 sites).

The plant remnants of rye (S. cereale), wheat (T. aestivum), durum wheat (T. durum) and einkorn wheat (T. monococcum) indicate that these cereal plant species were also grown in the area. Only in the Hallstatt period, and during no later period, the remains of oats (A. sativa) were found.

From the same period, oat was found in some Central Alpine regions and in France (Paušič and Šušek, 2020). Therefore, we assume that this taxon was already wide spread in that period.

Common flax (L. usitatissimum) was observed for the first time in this period (Table 2). Additional plant remains of grape vine, pea, broad bean and garden poppy (P. somniferum) were found also during the excavations of Iron Age sites from this period.

Our findings coincide with some other studies that highlight the importance of the two primitive wheat taxa, einkorn ( $T$. monococcum) and emmer (T. dicoccum) which were the most important taxa at that time in Europe. Studies show that einkorn was mainly grown in the southern facing slopes or lover places, while emmer was a staple throughout the region (Alonso and Bouby, 2017; Paušič and Šušek, 2020).

Spelt and einkorn wheats need less nitrogen than modern crops and are very resistant to weed competition. The importance of emmer lay principally in its ability to tolerate a wide variety of soil and climatic conditions; it also makes fewer demands regarding mineral and other chemical properties on the soil than some other cereals (Paušič and Šušek, 2020).

The other, indeed important cereal grown in the Iron Age in the broader region of Styria, was barley (highest abundance rate in the Hallstatt epoch, Table 2). Barley divided into tworow and six-row forms, respectively $H$. vulgare - distichum and $H$. vulgare - hexastichum, both of which could be hulled (with the husks attached to the grains) or naked. The early history of these two taxa is rather obscure. The naked and hulled barleys seem to have been important in the earlier phases of cereal cultivation in Europe, whereas the hulled varieties were preferred in later phases as threshing technology improved (Stika and Heiss, 2013; Paušič and Šušek, 2020). Both taxa were found during excavations in Central France, the Central Alpine area and in Styria (Paušič and Šušek, 2020). Therefore, we can conclude that those species were already widespread in the Central European area at that time.

Proso millet ( $P$. miliaceum) is a prevailing crop species, as it is evident from our study. The species is best suited for relatively dry, sandy soils. It has a short growing season and was especially important in Central and Southern Europe as a crop that could be sown in the spring and would ripen in the time of the summer harvest. In the early Iron Age, it may have been taken into cultivation first in the Balkans (Zohary et al., 2012). Proso millet was found also at other central European excavation sites and even in the Alpine areas of northern Italy (South Tyrol) (Heiss et al., 2005).

Oats (A. sativa) and rye ( $S$. cereale) are thought to have accompanied wheat and barley into Europe as weeds. They began to be cultivated in the Iron Age in Styria at a significant rate, usually at higher elevations. Optimum conditions for oats resemble those of wheat, but oats can ripen under wetter conditions and on more acidic soils, and so can be grown successfully where wheat cannot thrive - for example, in the higher settlement of the Styrian Alps (Schmidl et al., 2007).

The excavations at the Iron Age sites in the region of Styria show that they belong to cereals, but legumes were important too. The primary importance of legumes for the farmer is that these crops take nitrogen from the air and, through the symbiotic bacteria in the roots, feed both themselves and the soil. Legumes are of two morphological categories; the taxa that are sown annually, such as peas (Pisum sp.), broad beans ( $V . f a b a)$ and lupins (Lupinus spp.); and clovers which stand for several seasons, such as Trifolium sp. The lentil ( $L$. culinaris) as well as the broad bean ( $V$. faba) seed was found at many archaeological Iron Age sites and are therefore considered to be important pulse taxa, that were common (cultivated) in the studied area. Other studies indicate that the above mentioned taxa like the broad bean and the pea occurred regularly in alpine and prealpine regions of Central Europe and supplemented the diet of prehistoric settlers at that time (Barker, 1985; Schmidl et al., 2007).

With the addition of all the taxa cultivated at higher elevations of Styria (Alpine belt), other, more thermophylous were cultivated in flatland areas, taxa as common flax (L. usitatissimum) and breadseed or opium poppy ( $P$. somniferum). Remnants of those species were found during excavations in the studied area (Hack, 2002; Šoštarić et al., 2009; Šoštarić et al., 2017).

In Styria, throughout the Roman time (01 BC-5 AD), some important crops from previous epochs were still used as staple crops. According to the results of our study based on 72 remnants found at 8 study sites (Table 1, Fig. 2), the most frequently found cereals were barley (H. vulgare), which remnants were found at 6 study sites, followed by proso millet (P. miliaceum) (found at 5 study sites), common wheat (T. aestivum), foxtail millet and spelt wheat (all were found at 3 study sites). Interestingly, the remnants of rye (S. cereale) and einkorn wheat (T. monococcum) were not found at the archaeological sites of the studied area for that time frame (Table 2).

Another fact worth mentioning is that pulses were identified in the studied area in low quantities, compared to the findings from older time intervals (Table 2). This is the first time the remnants of Persian walnut (Juglans regia L.) were found in the studied area.

Many studies indicate that with the modernisation of road systems and better logistics it is possible to find archaeobotanical remnants of taxa used by Romans that otherwise do not thrive at northern latitudes of the studied area. The Romans included figs (Ficus carica L.), olives (Olea europaea L.), dates (Phoenix dactylifera L.) and other "exotic", non-native taxa in their daily diet, grown in their southern provinces. Even in Styria, some studies mention the findings of fig fruit and olive kernel remnants (Neef et al., 2012).

Interestingly, from this period we do not have any evidence for the presence of the common flax and the garden poppy in Styria (Table 2), which does not mean those taxa were not present here at that time. Simply, there are too many factors which influence the presence of a particular archaeobotanical remnant in a particular place.

Our study shows that in the late Antiquity and Middle 
Ages (start from around 5 AD), the remnants of lentil ( $L$. culinaris) (found at 7 archaeeological sites) and rye (S. cereale) (found at 6 archaeological sites) have the highest abundance rates, followed by proso millet ( $P$. miliaceum) (found at 4 sites) (Table 2).

One can conclude that basically all other cereal taxa, known from previous periods, also grew in this time frame. The exceptions are oat (A. sativa) and durum wheat (T. durum), which were not found for this time frame.

Some cultivars of plums and apples emerged as well as pear varieties with larger fruits, that were brought to the broader Central European area via trade routes. However, we have not found evidence of mass spread of these taxa, with the exception of three remnants of peach seed (Prunus persica (L.) Siebold \& Zucc)(Neef et al., 2012).

\section{CONCLUSIONS}

This study was primarily based on the occurrence analysis of the most important crop taxa in the studied area over a larger time period. The study shows a clear presence of some crops in all of the observed time periods, while some other taxa (e.g., the oat remnants) were found only in one or two of the studied time periods.

Importantly some methodological issues and limitations of the data interpretation clearly stand out. First of all, the area of study was not excavated evenly. The material came only from archaeological sites, which were linked to major settlements from a particular time. We do not have enough data, or no data at all, for parts of particular time periods. Consequently, we are not able to generalize results, nor produce any specific conclusions. We are able to solely say that the taxa occurred (or did not occur) in the studied period $\mathrm{A}$ at place $\mathrm{X}$. The second issue is that not all archaeological sites were investigated through all epochs or time frames. As a result, we sometimes have an open time window, for which we do not have any data. Lastly, our large datasets (the base we gained information from) often contained false determinations of taxa that were excluded at the end (a normal procedure in paleo botany, but all those data could not be used at the end). All those facts should be taken into account when interpreting the results and preparing any interregional and regional comparisons.

With the help of botanical evidence and paleobotanical remnants, we do know today that the majority of planted crop taxa used by the first Central European farmers were not native to that area. We also know that, apart from animals (cattle, dogs and pigs), the rest of the important cultivated plants (e.g., emmer, einkorn, barley, legumes etc.) and livestock from the Neolithic were most probably first domesticated in the Near East. Therefore, the simplest mechanism for the first entry and the subsequent spread across Europe of these "exotic" species, were most likely the migrations of colonising farmers and their trade.

The results of our study indicate that people in Styria certainly used proso millet and einkorn wheat in their staple diet during the Copper Age. Since these are non-native plant taxa (they were domesticated and were brought to the Central European area from the Middle East) and could not be harvested in the wild, we can conclude with certainty that those two taxa were among the first cultivated plants in Styria. The production of cultivated plants increased in the Bronze Age. During this period, which lasted from 2,300 to $900 \mathrm{BC}$ in Styria, we found all cultivated plants that were used in the diet even later throughout all time periods up to the Middle Ages. Among the 9 different cereals, barley, proso millet, emmer wheat, foxtail millet, and spelt wheat were most commonly found. In addition to cereals, legumes were also used and grown, mainly lentils, broad beans and peas. In addition, we also found garden poppy and grape seed.

The importance of individual cultivated plants could be defined according to the number of sites where its remains were found. Plant that residues found at a number of sites was probably more commonly used in the diet. In the period from the Bronze Age to the Middle Ages, we found that the most commonly grown cereals were barley, proso millet, emmer wheat, einkorn wheat, fox tail millet and spelt wheat. Of the legumes, lentil is the single most commonly found taxon, followed by broad bean and peas. The remnants of grape wine seed also occurred frequently throughout the observed time frame.

At the end it is important to mention the importance of native, wild fruit bearing species, which were consumed by local inhabitants during all observed time periods and are important for local cuisine even today (Colledge and Conolly, 2014). Some of the prominent native, wild-fruit bearing taxa (collected and used as a food source in the studied area from prehistory on) are: wild apple (Malus sylvestris (L.) Mill.), hazel nuts (Corylus avellana L.), sweet chestnut (Castanea sativa Mill.), strawberries (Fragaria spp.), raspberry (Rubus idaeus L.), black elderberry (Sambucus nigra L.), blackthorn (Prunus spinosa L.), cornelian cherry (Cornus mas L.), wild cherry (Prunus avium L.), service tree (Sorbus domestica L.), as well as many native herbal species.

However, wild plants obtained from foraging activities were also a component of subsistence economies and diets throughout the studied time periods. Since all those taxa belong to the native flora of the studied area and were already present in the forest and meadow communities from the prehistory onwards, we decided to exclude them from our study.

\section{REFERENCES}

1. Alonso, N., \& Bouby, L. (2017). Plant resources from the Bronze Age and the first Iron Age in the north-western arc of the Mediterranean Basin. Comptes Rendus Palevol, 16(4), 363-377.

2. Ammerman, A.J., \& Cavalli-Sforza, L.L. (1971). Measuring the rate of spread of early farming in Europe. Man New Series, 6, 674-688.

3. Ammerman, A.J., \& Cavalli-Sforza, L.L. (1984). The Neolithic transition and the genetics of populations in Europe. Princeton, United States: Princeton University Press.

4. Belfer-Cohen A., \& Bar-Yosef O. (2002) Early sedentism in the Near East. In: I. Kuijt (Ed.), Life in Neolithic farming communities. Fundamental issues in archaeology. Boston, MA: Springer. 
5. Barker, G. (1985). Prehistoric farming in Europe. Cambridge, United Kingdom: Cambridge University Press. Retrieved from: https://www.dlib.si/details/ URN:NBN:SI:doc-REJER4CW

6. Colledge, S., \& Conolly, J. (2014). Wild plant use in European Neolithic subsistence economies: a formal assessment of preservation bias in archaeobotanical assemblages and the implications for understanding changes in plant diet breadth. Quaternary Science Reviews, 101, 193-206. Retrieved from: https://doi. org/10.1016/j.quascirev.2014.07.013

7. Culiberg, M. (1999). Palaeobotany in Slovene archaeology. Arheološki vestnik, 50, 323-331.

8. Diamond, J. (2002). Evolution, consequences and future of plant and animal domestication. Nature, 418(689), 700-707. Retrieved from: https://www.nature.com/ articles/nature01019

9. Gkiasta, M., Russell, T., Shennan, S., \& Steele, S. (2003). Neolithic transition in Europe: The radiocarbon record revisited. Antiquity, 77(295), 45-62. Retrieved from: DOI: $10.1017 /$ S0003598X00061330

10. Hack, S. (2002). Der Wiesenkaisertumulus Nr. 4, eine hallstattzeitliche Bestattung in Goldes, Steiermark. Fundberichte aus Österreich, 41, 91-165.

11. Heiss, A.G., Kofler, W., \& Oeggl, K. (2005). The Ulten Valley in South Tyrol, Italy: Vegetation and settlement history of the area, and macrofossil record from the IronAge cult site of St. Walburg. Palyno-Bulletin, 1, 63-73.

12. Herbert, B. (2018). Urgeschichte und Römerzeit in der Steiermark - Geschichte der Steiermark, Band 1 (899 p.). Wienna, Austria: Verlag Böhlau.

13. Higgs, E.S., \& Jarman, M.R. (1972). The origins of animal and plant husbandry. Papers in Economic Prehistory, 10, 3-13.

14. Inter-Arch. (2021, January 11). Der Mensch und seine Landschaft. Retrieved from: http://www.interarchsteiermark.eu/

15. Jacomet, S. (2009). Plant economy and village life in Neolithic lake dwellings at the time of the Alpine Iceman. Vegetation History and Archaeobotany, 18, 4759. Retrieved from: https://doi.org/10.1007/s00334-0070138-2

16. Jarman, M.R., Bailey, G.N., \& Jarman, H.N. (1982). Early European Agriculture. Its foundation and Development. Cambridge, United Kingdom: Cambridge University Press.

17. Jeraj, M., Velušček, A., \& Jacomet, S. (2008). The diet of Eneolithic (Copper Age, Fourth millennium cal B.C.) pile dwellers and the early formation of the cultural landscape south of the Alps: a case study from Slovenia. Vegetation History and Archaeobotany, 18(1), 79-85. Retrieved from: https://doi.org/10.1007/s00334-0080144-Z

18. Kabir, M.H., Mimura, M., \& Tsai, J.C. (2018). Spreading waves in a farmers and hunter-gatherers model of the Neolithic transition in Europe. Bulletin of Mathematical Biology, 80(9), 2452-2480. Retrieved from: https://doi. org/10.1007/s11538-018-0475-6/

19. Lenneis, E. (2001). The beginning of the Neolithic in Austria - a report about recent and current investigations.
Documenta Praehistorica, 28, 99. Retrieved from: https:// doi.org/10.4312/dp.28.7

20. Neef, R., Cappers, R.T.J., Bekker, R.M., \& Boulos, L. (2012). Digital atlas of economic plants in archaeology. Groningen, The Nederlands: Barkhuis.

21. Paušič, A., \& Šušek, A. (2020). Iron Age farming in the Central European Alpine and Dinaric regions; crop occurrence and distribution. Agricultura, 15, 35-43. Retrieved from: https://doi.org/10.18690/agricultura.15.12.35-43.2018

22. Reed, K. (2016). Agricultural change in Copper Age Croatia (ca. 4500-2500 cal B.C)? Archaeological and Anthropological Sciences, 9(8), 1745-1765. Retrieved from: https://link.springer.com/article/10.1007/s12520-0160330-3

23. Schmidl, A., Jacomet, S., \& Oeggl, K.D. (2007). Distribution patterns of cultivated plants in the Eastern Alps (Central Europe) during Iron Age. Journal of Archaeological Science, 34(2), 243-254. Retrieved from: https://doi.org/10.1016/j. jas.2006.05.001

24. Stika, H.P., \& Heiss, A. (2013). Plant cultivation in the Bronze Age. The Oxford Handbook of European Bronze Age. Oxford, United Kingdom: Oxford University Press. Retrieved from: https://DOI:10.1093/oxfordhb/97801995 72861.013.0019

25. Šoštarić, R., Alegro, A., Hršak, V., Stančić, Z., \& Küster, H. (2009). Plant remains from an Early Iron Age well at Hajndl, Slovenia. Collegium Antropologicum, 33(4), 12951301. Retrieved from: https://www.researchgate.net/ publication/41147114_Plant_remains_from_an_Early_ Iron_Age_well_at_Hajndl_Slovenia

26. Šoštarić, R., Potrebica, H., Hršak, J., \& Essert, S. (2017). Archaeobotanical components of grave goods in prehistoric tumuli 6 and 7 at the archaeological site of Kaptol-Gradci, near Požega (Croatia). Acta Botanica Croatica, 76, 2. Retrieved from: https://doi.org/10.1515/ botcro-2017-0004

27. Weiss, E., \& Zohary, D. (2011). The Neolithic Southwest Asian founder crops. Their biology and archaeobotany. Current Anthropology, 52, 237-254. Retrieved from: https://doi.org/10.1086/658367

28. Zohary, D., Hopf, M., \& Weiss, E. (2012). Domestication of plants in the Old World. The origin and spread of domesticated plants in south-west Asia, Europe, and the Mediterranean Basin. 4th ed. New York, United States: Oxford University Press. 


\section{Pojavnost gojenih rastlin na področju Štajerske od paleolitika do srednjega veka}

\section{IZVLEČEK}

V delu so zbrani arheobotanični popisi rastlinskih makroostankov, najdenih v arheoloških grobiščih širšega območja Štajerske. Glavni namen tega preglednega članka je predstaviti najpomembnejše kultivirane rastline, ki jih je človek gojil v omenjeni regiji, $\mathrm{v}$ daljšem časovnem obdobju ali časovnem oknu. Rezultati raziskave kažejo, da je človek na območju Štajerske gojil proso (Panicum miliaceum) in pšenico enozrnico (Triticum monococcum), že v bakreni dobi. V bronasti dobi na omenjenem območju zasledimo rastlinske makroostanke ječmena (Hordeum vulgare) in pire (Triticum spelta), ter ostanke pšenice enozrnice in prosa. Železna doba je čas, ko na območju raziskav najdemo ostanke novih vrst poljščin. To sta laški muhvič (Setaria italica) in navadni lan (Linum usitatissimum). Za Štajersko je pomembno Rimsko obdobje, ko v regiji prvič najdemo makroostanke plodu navadnega oreha (Juglans regia). V antičnem obdobju ter v srednjem veku se v regiji pojavljajo številne pomembne vrste poljščin iz prejšnjih zgodovinskih obdobij, z izjemo ovsa (Avena sativa) in trde pšenice (Triticum durum), katerih rastlinski ostanki v obravnavanih grobiščih niso bili najdeni.

Ključne besede: arheobotanika, biogeografija, domestikacija poljščin, paleobotanika, Štajerska 